Article

\title{
Two-Dimensional Layered Double Hydroxide Derived from Vermiculite Waste Water Supported Highly Dispersed Ni Nanoparticles for CO Methanation
}

\author{
Panpan Li ${ }^{1}$, Mingyuan Zhu ${ }^{1}$, Zhiqun Tian ${ }^{2}$, Yang Han ${ }^{1}$, Yu Zhang ${ }^{3}$, Tuantuan Zhou ${ }^{3}$, \\ Lihua Kang ${ }^{1}$, Jianming Dan ${ }^{1}$, Xuhong Guo ${ }^{1,4}$, Feng Yu ${ }^{1, *}$, Qiang Wang ${ }^{1,3, *}$ and Bin Dai ${ }^{1, *}$ \\ 1 Key Laboratory for Green Processing of Chemical Engineering of Xinjiang Bingtuan, School of Chemistry \\ and Chemical Engineering, Shihezi University, Shihezi 832003, China; ppl_19910109@163.com (P.L.); \\ zhuminyuan@shzu.edu.cn (M.Z.); llccnn@stu.shzu.edu.cn (Y.H.); kanglihua@shzu.edu.cn (L.K.); \\ djm_tea@shzu.edu.cn (J.D.); guoxuhong@ecust.edu.cn (X.G.) \\ 2 Collaborative Innovation Center of Renewable Energy Materials, Guangxi University, Nanning 530004, \\ China; tianzhiqun@gxu.edu.cn \\ 3 Environmental Functional Nanomaterials (EFN) Laboratory, College of Environmental Science and \\ Engineering, Beijing Forestry University, Beijing 100083, China; hjzhangyu@bjfu.edu.cn (Y.Z.); \\ ztuant86@126.com (T.Z.) \\ 4 State Key Laboratory of Chemical Engineering, East China University of Science and Technology, \\ Shanghai 200237, China \\ * Correspondence: yufeng05@mail.ipc.ac.cn (F.Y.); qiangwang@bjfu.edu.cn (Q.W.); db_tea@shzu.edu.cn (B.D.); \\ Tel.: +86-993-2057277 (F.Y. \& Q.W. \& B.D.)
}

Academic Editor: Simon Penner

Received: 9 December 2016; Accepted: 1 March 2017; Published: 7 March 2017

\begin{abstract}
Expanded multilayered vermiculite (VMT) was successfully used as catalyst support and Ni/VMT synthesized by microwave irradiation assisted synthesis (MIAS) exhibited excellent performance in our previous work. We also developed a two-dimensional porous $\mathrm{SiO}_{2}$ nanomesh (2D VMT-SiO 2 ) by mixed-acid etching of VMT. Compared with three-dimensional (3D) MCM-41, 2D VMT-SiO 2 as a catalyst support provided a superior position for implantation of $\mathrm{NiO}$ species and the as-obtained catalyst exhibited excellent performance. In this paper, we successfully synthesized a layered double hydroxide (LDH) using the spent liquor after mixed-acid etching of VMT, which mainly contained $\mathrm{Mg}^{2+}$ and $\mathrm{Al}^{3+}$. The as-calcined layered double oxide (LDO) was used as a catalyst support for CO methanation. Compared with Ni/MgAl-LDO, Ni/VMT-LDO had smaller active component particles; therefore, in this study, it exhibited excellent catalytic performance over the whole temperature range of $250-500{ }^{\circ} \mathrm{C}$. Ni/VMT-LDO achieved the best activity with $87.88 \% \mathrm{CO}$ conversion, $89.97 \% \mathrm{CH}_{4}$ selectivity, and $12.47 \times 10^{-2} \cdot \mathrm{s}^{-1}$ turn over frequency (TOF) at $400{ }^{\circ} \mathrm{C}$ under a gas hourly space velocity of $20,000 \mathrm{~mL} / \mathrm{g} / \mathrm{h}$. This study demonstrated that VMT-LDO as a catalyst support provided an efficient way to develop high-performance catalysts for synthetic natural gas (SNG) from syngas.
\end{abstract}

Keywords: two-dimensional materials; layered double hydroxide (LDH); CO methanation; vermiculite

\section{Introduction}

Since carbon oxide methanation was discovered by Sabatier and Senderens in 1902, it has been well developed and widely used due to its capability as a chemical storage for excess $\mathrm{H}_{2}$ generated from renewable energy and a solution for greenhouse gas recycling [1-3]. Synthetic natural gas (SNG) via methanation can result in the clean utilization of coal and biomass, and this can prove to be an 
ideal method to solve the problem of the lack of natural gas in China [4,5]. In addition, methanation of carbon monoxide can also guarantee energy supplies, an important advantage owing to the increasing energy demand that accompanies the rapid development of the world economy.

$\mathrm{Al}_{2} \mathrm{O}_{3}$ has been one of the most commonly used catalyst supports due to its large specific surface area and moderate active component-support interaction [6]. The performance of an $\mathrm{Al}_{2} \mathrm{O}_{3}$-based catalyst is quite sensitive to the preparation method; catalysts prepared using solution combustion synthesis and the single-step sol-gel method can reduce the catalysts' disadvantages, such as sintering of Ni particles, facile carbon deposition, and severe sulfur poisoning at high temperature [7-11]. MgO as a promoter can also improve resistance to carbon deposition and minimize Ni particle sintering [12]. The $\mathrm{Ni} / \mathrm{MgO}$ catalyst has a strong interaction between $\mathrm{Ni}$ and $\mathrm{MgO}$, and $\mathrm{MgO}$ can depress the aggregation of $\mathrm{Ni}$ metal particles, leading to higher thermal stability and better performance $[13,14]$.

2D materials have excellent electronic properties and exceptional mechanical robustness, and are favorable to be used as catalyst supports [15]. As a kind of 2D material, layered double hydroxide (LDH) with the advantages of unique structure, composition diversity, high stability, easy preparation, and low cost has shown great potential in the design and synthesis of novel supported catalysts. LDH has been widely employed in the synthesis of Ni-based catalysts with a high degree of dispersion and stability by utilization of anchoring effects to enhance the immobilization of the active phase [16,17]. $\mathrm{Ni}-\mathrm{Al} \mathrm{LDHs}$ are found to be promising catalyst precursors for $\mathrm{CO}_{2}$ methanation reaction, and $\mathrm{Ni} / \mathrm{Al}_{2} \mathrm{O}_{3}$-LDO can decrease the $\mathrm{CO}_{2}$ methanation reaction temperature to $260{ }^{\circ} \mathrm{C}$ due to its high dispersion of $\mathrm{Ni}$, and $\mathrm{Fe}(\mathrm{III})$ can further decrease the $\mathrm{Ni}$ particle size, resulting a higher catalytic performance of $58.2 \%$ methane yield at $220^{\circ} \mathrm{C}[7,18]$. MgAl-LDH has been used as a catalyst support in oxidation reactions $[19,20]$, and the as-calcined samples, named layered double oxide (LDO) or mixed metal oxides (MMO) are also used as supports due to their large specific surface area and the strong interaction between active components and the support [16]. Li et al. [21] found that the NiMgAl-LDO catalyst showed excellent $\mathrm{CO}$ methanation performance in high-temperature region: 400-650 ${ }^{\circ} \mathrm{C}$, the transmission electron microscopy (TEM) and X-ray diffraction (XRD) results indicated that upon calcination of the $\mathrm{NiMgAl}-\mathrm{LDH}$ precursor, the $\mathrm{NiO}$ phase gains a strong interaction with $\mathrm{MgO}$ and/or $\mathrm{Al}_{2} \mathrm{O}_{3}$ to form a $\mathrm{Ni}_{x} \mathrm{Mg}_{1-x} \mathrm{O}$ solid solution, leading to high-temperature stability and high $\mathrm{Ni}$ dispersion. Fan et al. [12] used $\mathrm{Mg}-\mathrm{Al}$ oxide-supported $\mathrm{Ni}$ catalysts which not only have excellent thermal stability at high temperature, but also showed catalytic activity at low temperature of $250{ }^{\circ} \mathrm{C}$ with a Ni loading of $40 \mathrm{wt} \%$, which is ascribed to the large specific surface area and strong metal-support interaction. Buelens et al. [22] developed a "super-dry" $\mathrm{CH}_{4}$ reforming through Le Chatelier's principle reaction using $\mathrm{Ni} / \mathrm{MgAl}_{2} \mathrm{O}_{4}$ as a $\mathrm{CH}_{4}$-reforming catalyst. In this reaction $\mathrm{Fe}_{2} \mathrm{O}_{3} / \mathrm{MgAl}_{2} \mathrm{O}_{4}$ was used as a solid oxygen carrier and oxidized $\mathrm{CH}_{4}$ into $\mathrm{CO}_{2}$ and $\mathrm{H}_{2} \mathrm{O}$, while the $\mathrm{Fe}_{2} \mathrm{O}_{3}$ reduced to $\mathrm{Fe} ; \mathrm{CaO} / \mathrm{Al}_{2} \mathrm{O}_{3}$ as a $\mathrm{CO}_{2}$ sorbent formed $\mathrm{CaCO}_{3}$, then the $\mathrm{CaCO}_{3}$ decomposed into $\mathrm{CaO}$ and $\mathrm{CO}_{2}$, and $\mathrm{CO}_{2}$ reduced to $\mathrm{CO}$ by Fe through a redox reaction. Compared with conventional dry reforming, "super-dry" $\mathrm{CH}_{4}$ reforming can result in higher $\mathrm{CO}$ production, and showed both practical and economic benefits.

We have developed a type of 2D porous $\mathrm{SiO}_{2}$ nanomesh from a mixed-acid etching of 2D expanded multilayered vermiculite (EML-VMT). In this paper we synthesized a 2D VMT-LDH using the spent liquor, which contains $\mathrm{Mg}^{2+}, \mathrm{Al}^{3+}$, etc., with a $\mathrm{Mg} / \mathrm{Al}$ molar ratio of 1.5:1 [23,24]. The spent liquor also contains a small amount of $\mathrm{Fe}^{2+}$ and $\mathrm{Ca}^{2+}$. $\mathrm{Fe}$ as the best promoter, can combine with $\mathrm{Ni}$ to form enhanced methanation catalysts, and Ca can improve the dispersion of nickel [25-27]. The as-calcined 2D VMT-LDO was used as a catalyst support for CO methanation and Ni/VMT-LDO exhibited better catalytic performance than $\mathrm{Ni} / \mathrm{MgAl}-\mathrm{LDO}$ in the entire temperature range. This VMT-LDH catalyst support realized recycling utilization of the spent liquors, effectively preventing the metal ions in the spent liquors pollute the environment at the same time. 


\section{Results and Discussion}

\subsection{XRD, SEM, and TEM Characterization of LDHS and LDOS}

From Figure 1a, MgAl-LDH and VMT-LDH presented the characteristic diffraction peaks of a well-crystallized LDH phase (JCPDS NO. 22-0452) at $2 \theta$ of $11.71^{\circ}, 34.33^{\circ}, 61.34^{\circ}$, and $62.68^{\circ}$, corresponding to the reflections of planes (001), (100), (110), and (111), respectively. The diffraction peaks indicated that the LDH was successfully synthesized by using the spent liquor after mixed dilute aqua regia solution etching of vermiculite. After calcining at $550{ }^{\circ} \mathrm{C}$ for $5 \mathrm{~h}$ in a muffle furnace, the as-obtained MgAl-LDO and VMT-LDO (Figure 1b) showed the characteristic diffraction peaks of MgO (JCPDS NO. 65-0476) at $2 \theta$ of $36.94^{\circ}, 42.92^{\circ}$, and $62.30^{\circ}$, corresponding to crystal lattice indices of (111), (200), and (220), respectively. No peaks indicative of $\mathrm{Al}_{2} \mathrm{O}_{3}$ species was detected in either MgAl-LDO or VMT-LDO, these observations suggested that $\mathrm{Al}_{2} \mathrm{O}_{3}$ was in an amorphous state or that $\mathrm{Al}^{3+}$ ions became incorporated into $\mathrm{MgO}$ to form spinel phases, such as $\mathrm{MgAl}_{2} \mathrm{O}_{4}$ [28-30]. The SEM and TEM images of the as-obtained LDOs are displayed in Figure 2. The plate-like structure of VMT-LDO can be obviously seen in the TEM images. The stratified structure as perfect as MgAl-LDO, which is more evidence that VMT-LDH was successfully synthesized. The Brunauer-Emmett-Teller (BET) surface of MgAl-LDO and VMT-LDO were $177.3 \mathrm{~m}^{2} / \mathrm{g}$ and $72.4 \mathrm{~m}^{2} / \mathrm{g}$ respectively.
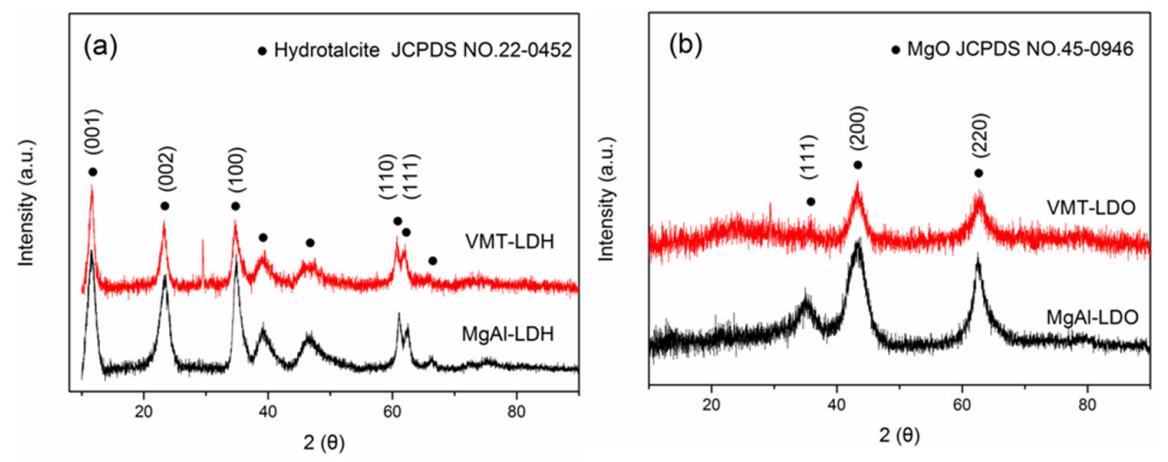

Figure 1. (a) X-ray diffraction (XRD) patterns of MgAl-LDH and VMT-LDH; (b) XRD patterns of MgAl-LDO and VMT-LDO.
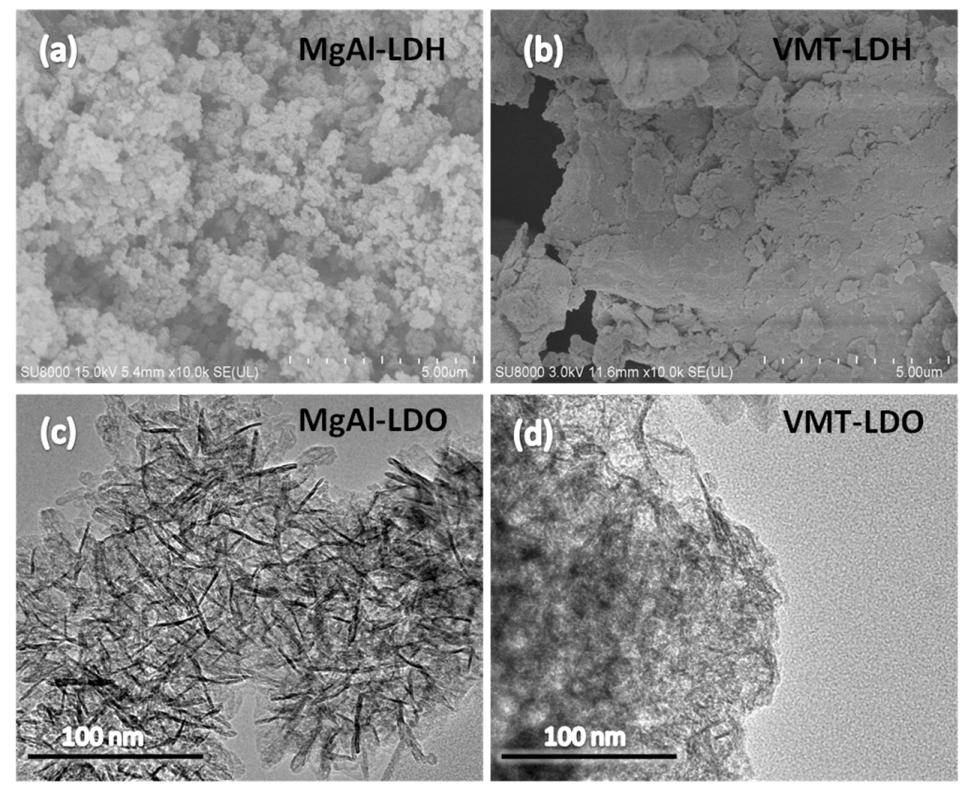

Figure 2. SEM images of (a) MgAl-LDH; (b) VMT-LDH; TEM images of (c) MgAl-LDO and (d) VMT-LDO. 


\subsection{XRD and TEM Characterization of Catalysts}

Wide-angle XRD patterns of the as-calcined catalysts are shown in Figure 3a. Characteristic peaks of $\mathrm{NiO}$ (JCPDS NO. 65-5745) were distinctly observed at $2 \theta$ of $37.25^{\circ}, 43.27^{\circ}$, and $62.88^{\circ}$ for catalysts $\mathrm{NiO} / \mathrm{MgAl}-\mathrm{LDO}$ and $\mathrm{NiO} / \mathrm{VMT}-\mathrm{LDO}$, corresponding to the reflections of planes (111), (200), and (220), respectively. Figure 3c, d show TEM images of the catalysts, as well as the surrounding structures. It can be seen clearly that the particle sizes of $\mathrm{NiO} / \mathrm{MgAl}-\mathrm{LDO}$ were larger than those of NiO/VMT-LDO. The majority of active component particles of NiO/ MgAl-LDO were around $20 \mathrm{~nm}$ in size, and the average $\mathrm{NiO}$ particle size obtained from TEM images was $18.1 \mathrm{~nm}$. Whereas for $\mathrm{NiO} / \mathrm{VMT}-\mathrm{LDO}$, the $\mathrm{NiO}$ particle size was around $2 \mathrm{~nm}$, and the average $\mathrm{NiO}$ particle size was $2.3 \mathrm{~nm}$, which indicated that the $\mathrm{Ca}$ and Fe modification might be able to improve the dispersion of nickel $[18,25]$. The specific surface areas of all samples are displayed in Table 1 , and the catalysts $\mathrm{NiO} / \mathrm{MgAl}-\mathrm{LDO}$ and $\mathrm{NiO} / \mathrm{VMT}-\mathrm{LDO}$ gave areas of $52.5 \mathrm{~m}^{2} / \mathrm{g}$ and $53.1 \mathrm{~m}^{2} / \mathrm{g}$, respectively.
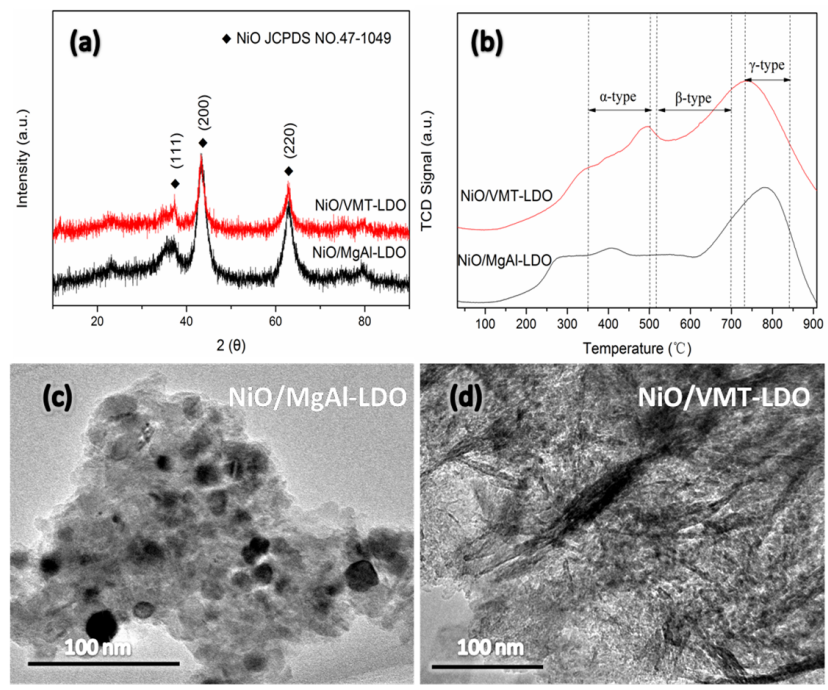

Figure 3. (a) XRD patterns of $\mathrm{NiO} / \mathrm{MgAl}-\mathrm{LDO}, \mathrm{NiO} / \mathrm{VMT}-\mathrm{LDO}$; (b) TPR profiles of $\mathrm{NiO} / \mathrm{MgAl}-\mathrm{LDO}$ and $\mathrm{NiO} /$ VMT-LDOTEM images of (c) NiO/MgAl-LDO and (d) NiO/VMT-LDO.

Table 1. Structural physical properties of the supports and catalysts.

\begin{tabular}{cccc}
\hline Samples & $\boldsymbol{S}_{\text {BET }}\left(\mathbf{m}^{\mathbf{2}} \cdot \mathbf{g}^{-\mathbf{1}} \mathbf{~}^{\mathbf{a}}\right.$ & Pore Volume $\left(\mathbf{c m}^{\mathbf{3}} \cdot \mathbf{g}^{-\mathbf{1}} \mathbf{)} \mathbf{b}\right.$ & Pore Size $(\mathbf{n m})^{\mathbf{b}}$ \\
\hline MgAl-LDO & 177.3 & 0.76 & 14.90 \\
NiO/MgAl-LDO & 52.5 & 0.15 & 3.91 \\
$\mathrm{Ni}$ /MgAl-LDO (used) & 45.0 & 0.22 & 24.98 \\
VMT-LDO & 72.4 & 0.16 & 7.36 \\
NiO/VMT-LDO & 53.2 & 0.22 & 5.63 \\
$\mathrm{Ni} /$ VMT-LDO (used) & 46.2 & 0.20 & 3.91 \\
\hline
\end{tabular}

a Obtained from the Brunauer-Emmett-Teller (BET) method. ${ }^{\text {b }}$ Obtained from the Barrett-Joyner-Halenda (BJH) desorption average pore volume and pore diameter.

\subsection{TPR Characterization of Catalysts}

The surface state and the reduction behavior of the catalysts NiO/VMT-LDO and NiO/MgAl-LDO were analyzed by $\mathrm{H}_{2}$-TPR measurement (Figure $3 b$ ). There were three reduction peaks of $\mathrm{NiO}$ species observed in the $\mathrm{H}_{2}$-TPR profile, which could be classified into three types: free nickel oxides possessing a weak interaction with the support $\left(350-500{ }^{\circ} \mathrm{C}, \alpha\right.$-type); $\mathrm{NiO}$ species that have a stronger interaction with the support (520-700 ${ }^{\circ} \mathrm{C}, \beta$-type); the reduction peaks of $\mathrm{MgNiO}_{2}$ solid solution (730-850 ${ }^{\circ} \mathrm{C}, \gamma$-type) [10,21]. The first two reduction temperatures of NiO/VMT-LDO were centered at $338^{\circ} \mathrm{C}$ and $491^{\circ} \mathrm{C}$, respectively. While the first two peaks' reduction temperatures of $\mathrm{NiO} / \mathrm{MgAl}-\mathrm{LDO}$ 
were centered at $284^{\circ} \mathrm{C}$ and $410{ }^{\circ} \mathrm{C}$, respectively. The reduction temperatures of NiO/VMT-LDO were slightly higher than those of $\mathrm{NiO} / \mathrm{MgAl}-\mathrm{LDO}$, suggesting that the interaction between $\mathrm{NiO}$ particles and VMT-LDO was stronger than that in MgAl-LDO. However, all of the reduction temperatures were below $500{ }^{\circ} \mathrm{C}$, which meant that they belong to the $\alpha$-type and could be reduced to generate active sites during the pretreatment before reaction. $\mathrm{MgNiO}_{2}$ solid solution could not be reduced in pretreatment or during the reaction due to the strong interaction between $\mathrm{Ni}$ and $\mathrm{MgO}$, resulting in a higher thermal stability [13].

\subsection{Catalytic Performance of Catalysts}

The $\mathrm{CO}$ methanation performance of the catalysts were carried out in the temperature range $250{ }^{\circ} \mathrm{C}-500{ }^{\circ} \mathrm{C}$, as shown in Figure $4 \mathrm{a}$. Ni/MgAl-LDO had shown no activity below $350{ }^{\circ} \mathrm{C}$, and when the reaction temperature reached $400{ }^{\circ} \mathrm{C}$, the catalyst $\mathrm{Ni} / \mathrm{MgAl}-\mathrm{LDO}$ showed $79.5 \% \mathrm{CO}$ conversion, and the catalytic performance had shown no decline at the higher temperature. For Ni/VMT-LDO, the catalyst not only showed low-temperature activity at $250{ }^{\circ} \mathrm{C}$, but also exhibited better catalytic performance than $\mathrm{Ni} / \mathrm{MgAl}-\mathrm{LDO}$ over the whole temperature range, reaching a maximum $\mathrm{CO}$ conversion of $87.9 \%$ at $400{ }^{\circ} \mathrm{C}$, additionally. The higher catalytic performance was no doubt due to the smaller and higher dispersion of active components particle size. The trend of $\mathrm{CH}_{4}$ selectivity (Figure $4 \mathrm{~b}$ ) for $\mathrm{Ni} / \mathrm{MgAl}-\mathrm{LDO}$ was in good agreement with that of $\mathrm{CO}$ conversion for Ni/MgAl-LDO in the temperature region: $250{ }^{\circ} \mathrm{C}-400{ }^{\circ} \mathrm{C}$, and declined with the temperature, which resulted from the carbon deposition and the agglomeration of the active Ni component. When it came to the catalyst Ni/VMT-LDO, which showed an interesting curve of $\mathrm{CH}_{4}$ selectivity, the $\mathrm{CH}_{4}$ selectivity of $\mathrm{Ni} / \mathrm{VMT}-\mathrm{LDO}$ declined at $350{ }^{\circ} \mathrm{C}$ compared with $300{ }^{\circ} \mathrm{C}$. Both samples obtained a maximum $\mathrm{CH}_{4}$ selectivity at $400{ }^{\circ} \mathrm{C}$. See Table 2 for a comparison of catalytic performance in different works.

It can be clearly seen in Figure 4c that Ni/VMT-LDO exhibited a higher turnover frequency (TOF) than $\mathrm{Ni} / \mathrm{MgAl}-\mathrm{LDO}$ over the whole temperature range. Ni/VMT-LDO reached a maximum TOF of $12.47 \times 10^{-2} \cdot \mathrm{s}^{-1}$ at $400{ }^{\circ} \mathrm{C}$, while for Ni/MgAl-LDO, a TOF value of $11.29 \times 10^{-2} \cdot \mathrm{s}^{-1}$ was achieved at the same temperature. The highest TOF value of Ni/MgAl-LDO catalyst was $11.57 \times 10^{-2} \cdot \mathrm{s}^{-1}$ at $500{ }^{\circ} \mathrm{C}$. Ni/VMT-LDO also achieved a higher $\mathrm{CH}_{4}$ yield in the whole temperature range compared with the catalyst Ni/MgAl-LDO (Figure 4 d), the highest $\mathrm{CH}_{4}$ yield was obtained at $400{ }^{\circ} \mathrm{C}$ for both samples. When the reaction temperature was higher than $400^{\circ} \mathrm{C}$, the $\mathrm{CH}_{4}$ yield decreased with the temperature increased. However, $\mathrm{Ni} / \mathrm{MgAl}-\mathrm{LDO}$ and $\mathrm{Ni} / \mathrm{VMT}-\mathrm{LDO}$ still have $\geq 70 \% \mathrm{CH}_{4}$ yield at $500{ }^{\circ} \mathrm{C}$. All of these results indicate that the catalytic performance of Ni/VMT-LDO catalyst was much better than that of $\mathrm{Ni} / \mathrm{MgAl}-\mathrm{LDO}$ catalyst.
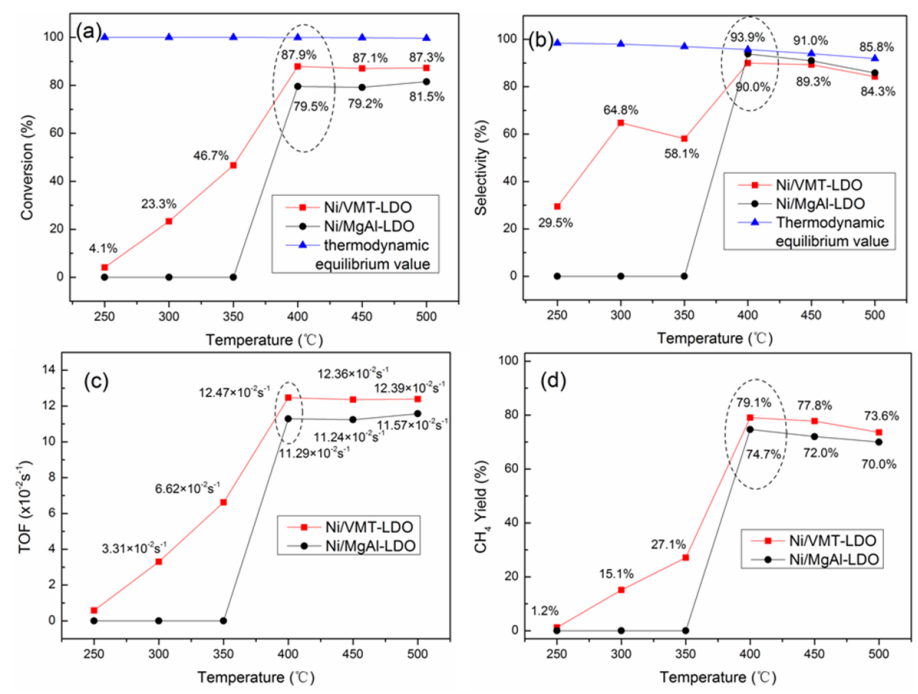

Figure 4. (a) $\mathrm{CO}$ conversion; (b) $\mathrm{CH}_{4}$ selectivity; (c) turnover frequency (TOF) and (d) $\mathrm{CH}_{4}$ yield of $\mathrm{Ni} / \mathrm{MgAl}-\mathrm{LDO}$ and Ni/VMT-LDO. 
Table 2. The comparison of catalytic performance in different works.

\begin{tabular}{|c|c|c|c|c|c|c|}
\hline Catalysts & $\begin{array}{c}\text { Optical } \\
\text { Temperature } \\
\left({ }^{\circ} \mathrm{C}\right)\end{array}$ & $\begin{array}{l}\text { Pressure } \\
\text { (MPa) }\end{array}$ & $\begin{array}{l}\text { Space } \\
\text { Velocity } \\
(\mathrm{mL} / \mathrm{g} / \mathrm{h})\end{array}$ & $\begin{array}{c}\mathrm{CO} / \mathrm{CO}_{2} \\
\text { Conversion (\%) }\end{array}$ & $\begin{array}{c}\mathrm{CH}_{4} \\
\text { Selectivity } \\
(\%)\end{array}$ & Ref. \\
\hline $40 \mathrm{wt} \% \mathrm{NiMgAl}-\mathrm{LDO}$ & 250 & 0.1 & 40,000 & $98.4\left(\mathrm{CO}_{2}+\mathrm{CO}\right)$ & 100 & [12] \\
\hline $78 \mathrm{wt} \%$ NiAl-LDO & 350 & 0.1 & 75,000 & $82.5\left(\mathrm{CO}_{2}\right)$ & 99.5 & [30] \\
\hline $\mathrm{NiAl}-\mathrm{LDO}\left(\mathrm{NiAl}_{4}\right)$ & 400 & 0.1 & 300,000 & $100(\mathrm{CO})$ & 92 & {$[17]$} \\
\hline $11 \mathrm{wt} \% \mathrm{NiMgAl}-\mathrm{LDO}$ & 400 & - & $15,000 \mathrm{~h}^{-1}$ & $99.9(\mathrm{CO})$ & 73.6 & [21] \\
\hline 10 wt $\%$ Ni/MgAl-LDO & 400 & 1.5 & 20,000 & $79.5(\mathrm{CO})$ & 93.9 & this work \\
\hline 10 wt \% Ni/VMT-LDO & 400 & 1.5 & 20,000 & $87.9(\mathrm{CO})$ & 90.0 & this work \\
\hline
\end{tabular}

\subsection{TEM and XRD Characterization of the Used Catalysts}

After reaction, as shown in Figure 5, both catalysts Ni/MgAl-LDO (used) and Ni/VMT-LDO (used) exhibited no obvious agglomeration, and especially for catalyst Ni/VMT-LDO (used) there were no obvious Ni particles to be seen, the absence of Ni particles in the catalysts being due to the smaller Ni particles and the formation of $\mathrm{Ni}-\mathrm{Mg}$ solid solutions [21]. XRD patterns of the used catalysts are shown in Figure 6. For Ni/MgAl-LDO (used) and Ni/VMT-LDO (used), both samples showed the diffraction peaks of metal Ni (JCPDS NO. 65-0380) at $2 \theta$ of $44.35^{\circ}, 51.67^{\circ}$, and $76.09^{\circ}$. Diffraction peaks of $\mathrm{MgNiO}_{2}$ (JCPDS NO. 24-0712) could also be seen at $2 \theta$ of $37.10^{\circ}, 43.10^{\circ}$, and $62.59^{\circ}$, which was another argument in favor of the formation of $\mathrm{Ni}-\mathrm{Mg}$ solid solutions. The $\mathrm{MgNiO}_{2}$ solid solution inhibited the agglomeration of Ni nanoparticles, which maintained high $\mathrm{CO}$ conversion and thermal stability at high temperatures. However, for Ni/MgAl-LDO (used), the diffraction peaks of spinel $\left(\mathrm{MgAl}_{2} \mathrm{O}_{4}\right)$ could be observed at $2 \theta$ of $19.03^{\circ}, 31.27^{\circ}, 36.85^{\circ}, 44.83^{\circ}, 55.66^{\circ}, 59.37^{\circ}$, and $65.24^{\circ}$, suggesting spinel $\left(\mathrm{MgAl}_{2} \mathrm{O}_{4}\right)$ formation during the reaction. Spinel could promote catalytic performance, leading to enhanced reactivity with increasing temperature [12,31].
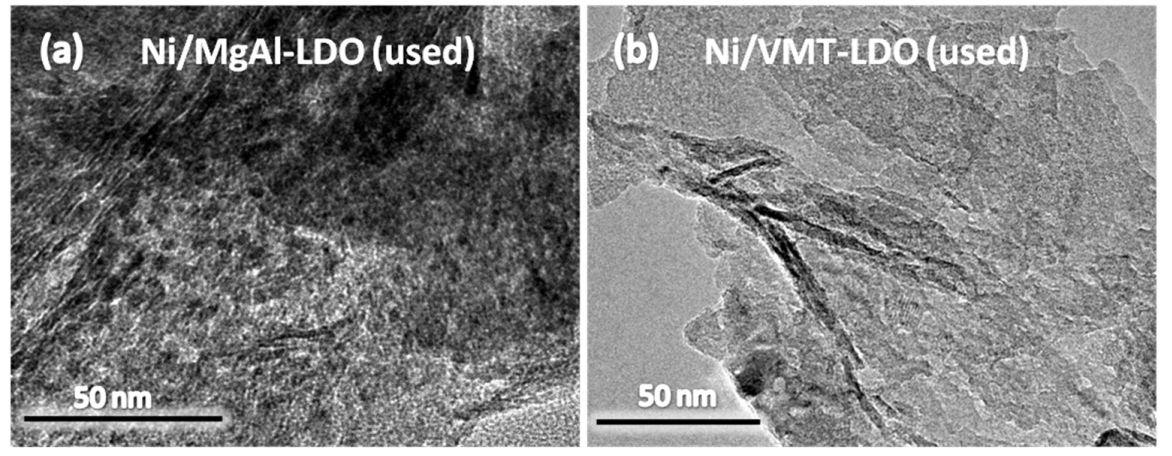

Figure 5. TEM images of (a) Ni/MgAl-LDO (used) and (b) Ni/ VMT-LDO (used).

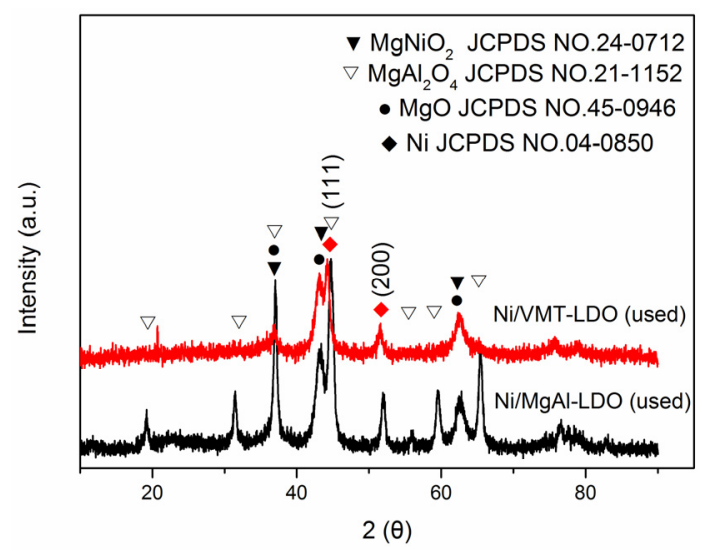

Figure 6. X-ray diffraction pattern of Ni/MgAl-LDO (used) and Ni/ VMT-LDO (used). 


\section{Materials and Methods}

\subsection{Catalyst Preparation}

The procedure to prepare expanded multilayered vermiculite (EML-VMT) followed the protocol as described in our previous work [24]. The schematic of the preparation process of VMT-LDH is displayed in Figure 7, vermiculite was expanded by $\mathrm{H}_{2} \mathrm{O}_{2}$ to obtain the EML-VMT, then the EML-VMT was etched with acid to remove $\mathrm{SiO}_{2}$. Subsequently the spent liquor was used to prepare LDH. The LDO was obtained by calcination of $\mathrm{LDH}$, and then the catalyst was prepared through the impregnation method.

Specific steps to prepare the LDH using the spent liquor are as follows: a $200 \mathrm{~mL}$ portion of $6 \mathrm{M}$ mixed acid solution (hydrochloric acid and nitric acid with volume ratio of 3:1) was placed into round-bottom flask equipped with a reflux condenser. Ten grams of EML-VMT was added and boiled in the flask at $80{ }^{\circ} \mathrm{C}$ for $4 \mathrm{~h}$ with constant stirring. The obtained samples were filtered. The filtrate, which mainly contained $\mathrm{Mg}^{2+}$ and $\mathrm{Al}^{3+}$, was collected and neutralized by adding $4 \mathrm{M} \mathrm{NaOH}$ until precipitates started to appear in the solution. Then, the filtrate solution was added dropwise to $\mathrm{Na}_{2} \mathrm{CO}_{3}$ solution $(100 \mathrm{~mL})$ containing 0.04 mol $\mathrm{Na}_{2} \mathrm{CO}_{3}$, the $\mathrm{pH}$ value of the mixture was kept constant at 10 by addition of $4 \mathrm{M} \mathrm{NaOH}$ and then the solution was aged at room temperature for $4 \mathrm{~h}$ with continuous stirring. Afterwards, the mixture was filtered and washed with deionized water until $\mathrm{pH}=7$ and then dispersed with acetone for $2 \mathrm{~h}$. The sample was filtered and washed with acetone again and then left to dry at $60^{\circ} \mathrm{C}$ in an oven. The as-obtained support was denoted as VMT-LDH. In comparison, the MgAl-LDH with an $\mathrm{Mg} / \mathrm{Al}$ molar ratio of 1.5:1 was also synthesized. Then VMT-LDH and MgAl-LDH were calcined at $550{ }^{\circ} \mathrm{C}$ for $4 \mathrm{~h}$, and the as-obtained layered double oxides named VMT-LDO and MgAl-LDO.

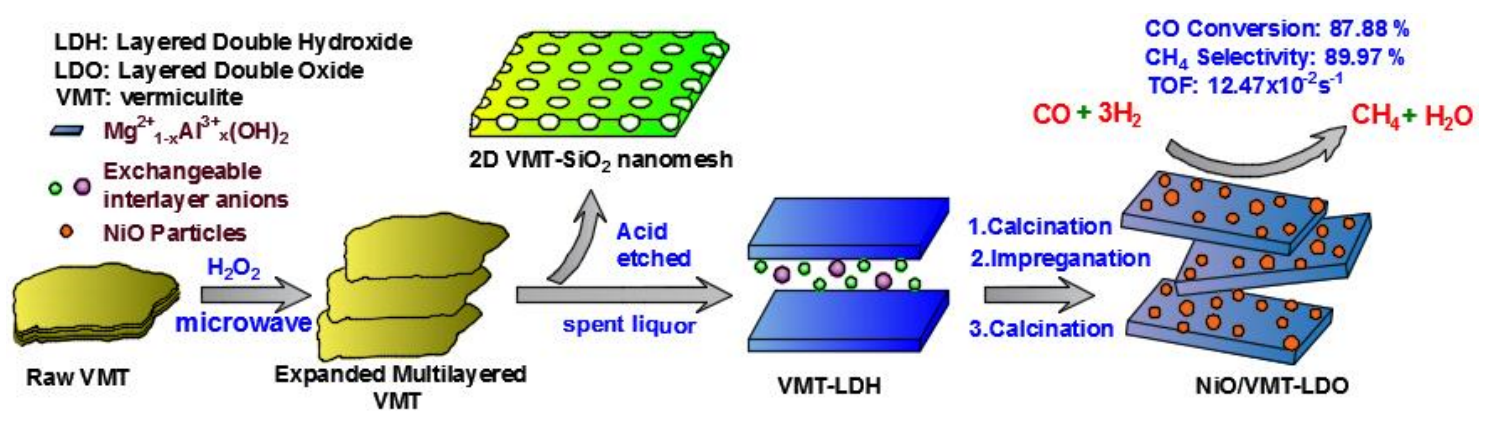

Figure 7. Schematic of the preparation process of VMT-LDH and NiO/VMT-LDH.

The catalyst was prepared using an impregnation method; the support (VMT-LDO or MgAl-LDO) was impregnated with an aqueous solution which contains certain quantities of $\mathrm{Ni}\left(\mathrm{NO}_{3}\right)_{2} \cdot 6 \mathrm{H}_{2} \mathrm{O}$ to achieve $10 \mathrm{wt} \% \mathrm{Ni}$ loading, with vigorous stirring under the conditions of $80{ }^{\circ} \mathrm{C}$ for $12 \mathrm{~h}$, and then evaporating the liquid. The as-prepared precursor was subsequently dried at $110{ }^{\circ} \mathrm{C}$ for $12 \mathrm{~h}$ and further calcined at $550{ }^{\circ} \mathrm{C}$ for $4 \mathrm{~h}$ in air at the heating rate of $10^{\circ} \mathrm{C} / \mathrm{min}$. The obtained catalysts were denoted as $\mathrm{NiO} / \mathrm{VMT}-\mathrm{LDO}$ and $\mathrm{NiO} / \mathrm{MgAl}-\mathrm{LDO}$.

\subsection{Characterization of Samples}

Powder X-ray diffraction (XRD) patterns were carried out on a Bruker D8 Advance X-ray diffractometer (Bruker Biosciences Corporation, Billerica, MA, USA) operated at $40 \mathrm{kV}$ and $40 \mathrm{~mA}$ with $\mathrm{Cu} \mathrm{K} \alpha$ radiation $(\lambda=0.15406 \mathrm{~nm})$. The Brunauer-Emmett-Teller (BET) specific surface area and Barrett-Joyner-Halenda (BJH) pore structure of the catalysts were evaluated using a Micromeritics ASAP 2020 BET apparatus (Micromeritics Instrument Ltd., Norcross, GA, USA). The Micromeritics TPx System (Micromeritic ASAP 2720, Micromeritics Instrument Ltd., Norcross, GA, USA) was also employed to analysis the $\mathrm{H}_{2}$ temperature programmed reduction $\left(\mathrm{H}_{2}-\mathrm{TPR}\right)$ properties of catalysts 
in a temperature range from room temperature to $900{ }^{\circ} \mathrm{C}$, with a gas $\left(10 \mathrm{vol} \% \mathrm{H}_{2} / \mathrm{Ar}\right)$ flow rate of $40 \mathrm{~mL} / \mathrm{min}$ and a heating rate of $10^{\circ} \mathrm{C} / \mathrm{min}$. Scanning electron microscopy (SEM) (Hitachi S-4300, Hitachi Limited, Japan) and transmission electron microscopy (TEM) (TecnaiG2 F20, FEI Instrument Ltd., Hillsboro, OR, USA) were employed to observe the microscopic of the catalysts.

\subsection{Catalytic Performance Evaluation}

The evaluation of $\mathrm{CO}$ methanation performance of the catalysts were performed in a fixed bed reactor at $1.5 \mathrm{Mpa}$, with a stainless steel tubular microreactor. Prior to the feed syngas $\mathrm{H}_{2} / \mathrm{CO}$ with a volume ratio of 3:1 was introduced to the reactor, the catalyst $(0.2 \mathrm{~g})$ was activated in $28 \mathrm{~mL} / \mathrm{min} \mathrm{H}_{2}$ at $500{ }^{\circ} \mathrm{C}$ for $2 \mathrm{~h}$. Then the feed syngas introduced to the reactor with a gas flow rate of $65 \mathrm{~mL} / \mathrm{min}$ and a weight space velocity of $20,000 \mathrm{~mL} / \mathrm{g} / \mathrm{h}$, and the catalytic performance of the catalysts were evaluated in the temperature region of $250-500{ }^{\circ} \mathrm{C}$. The outlet gases were analyzed by gas chromatography (GC-2014C, SHIMADZU) (GC-2014C, Shimadzu, Kyoto, Japan) online.

\section{Conclusions}

In this work, layered double hydroxide (LDH) was successfully synthesized, and the as-calcined layered double oxide (LDO) was used as a support for $\mathrm{CO}$ methanation. The as-obtained catalyst $\mathrm{Ni}$ /VMT-LDO had smaller Ni nanoparticles compared with catalyst Ni/MgAl-LDO, which was ascribed to Fe and Ca modification improved the dispersion of nickel, which resulted in a low temperature activity. The stronger metal-support interaction between Ni and VMT-LDO maintained the higher catalytic performance than the catalyst $\mathrm{Ni} / \mathrm{MgAl}-\mathrm{LDO}$ at higher temperature, so it was no doubt that the catalyst Ni/VMT-LDO exhibited excellent catalytic performance and thermal stability over the whole temperature range. Compared with Ni/MgAl-LDO, Ni/VMT-LDO achieved a better catalytic performance at $400{ }^{\circ} \mathrm{C}$, including a $87.88 \% \mathrm{CO}$ conversion, $89.97 \% \mathrm{CH}_{4}$ selectivity, $12.47 \times 10^{-2} \cdot \mathrm{s}^{-1}$ turn over frequency (TOF) and $79.1 \% \mathrm{CH}_{4}$ yield. This study demonstrated that VMT-LDO was a superior catalyst support to develop a catalyst for synthesis of SNG from syngas, and the VMT-LDO which contains Fe and Ca can also be used as catalyst support in other catalytic systems, such as super-dry reformation of methane.

Acknowledgments: This work was financially supported by National Natural Science Foundation of China (No. U1203293), the Doctor Foundation of Bingtuan (No. 2014BB004), the Program for Changjiang Scholars, Innovative Research Team in University (No. IRT_15R46), and the Program of Science and Technology Innovation Team in Bingtuan (No. 2015BD003).

Author Contributions: Feng Yu, Qiang Wang, and Bin Dai designed and conceived the experiments; Panpan Li, Yang Han, Yu Zhang, and Tuantuan Zhou performed the experiments, Panpan Li, Mingyuan Zhu, Zhiqun Tian, Lihua Kang, Jianming Dan, and Xuhong Guo analyzed the data; Panpan Li and Feng Yu wrote the paper. All authors participated in the analysis, interpretation, and review of the results and provided input in the writing process of the paper.

Conflicts of Interest: The authors declare no conflict of interest.

\section{References}

1. Centi, G.; Quadrelli, E.A.; Perathoner, S. Catalysis for $\mathrm{CO}_{2}$ conversion: A key technology for rapid introduction of renewable energy in the value chain of chemical industries. Energy Environ. Sci. 2013, 6, 1711-1731. [CrossRef]

2. Cheng, D.D.; Negreiros, F.R.; Aprà, E.; Fortunelli, A. Computational approaches to the chemical conversion of carbon dioxide. ChemSusChem 2013, 6, 944-965. [CrossRef] [PubMed]

3. Sabatier, P.; Senderens, J. New Synthesis of Methane. Comptes Rendus Hebdomadaires des Seances del Academie des Scrences 1902, 134, 514-516.

4. Kopyscinski, J.; Schildhauer, T.J.; Biollaz, S.M.A. Production of synthetic natural gas (sng) from coal and dry biomass-A technology review from 1950 to 2009. Fuel 2010, 89, 1763-1783. [CrossRef]

5. Seemann, M.C.; Schildhauer, T.J.; Biollaz, S.M.A. Fluidized bed methanation of wood-derived producer gas for the production of synthetic natural gas. Ind. Eng. Chem. Res. 2010, 49, 7034-7038. [CrossRef] 
6. Hu, D.; Gao, J.; Ping, Y.; Jia, L.; Gunawan, P.; Zhong, Z.; Xu, G.; Gu, F.; Su, F. Enhanced investigation of CO methanation over $\mathrm{Ni} / \mathrm{Al}_{2} \mathrm{O}_{3}$ catalysts for synthetic natural gas production. Ind. Eng. Chem. Res. 2012, 51, 1254-1262. [CrossRef]

7. Gabrovska, M.; Edreva-Kardjieva, R.; Crişan, D.; Tzvetkov, P.; Shopska, M.; Shtereva, I. Ni-Al layered double hydroxides as catalyst precursors for $\mathrm{CO}_{2}$ removal by methanation. React. Kinet. Mech. Catal. 2012, 105, 79-99. [CrossRef]

8. Mirodatos, C.; Praliaud, H.; Primet, M. Deactivation of nickel-based catalysts during CO methanation and disproportionation. J. Catal. 1987, 107, 275-287. [CrossRef]

9. Struis, R.P.W.J.; Schildhauer, T.J.; Czekaj, I.; Janousch, M.; Biollaz, S.M.A.; Ludwig, C. Sulphur poisoning of Ni catalysts in the sng production from biomass: A TPO/XPS/XAS study. Appl. Catal. A Gen. 2009, 362, 121-128. [CrossRef]

10. Zhao, A.; Ying, W.; Zhang, H.; Ma, H.; Fang, D. Ni- $\mathrm{Al}_{2} \mathrm{O}_{3}$ catalysts prepared by solution combustion method for syngas methanation. Catal. Commun. 2012, 17, 34-38. [CrossRef]

11. Hwang, S.; Lee, J.; Hong, U.G.; Seo, J.G.; Ji, C.J.; Dong, J.K.; Lim, H.; Byun, C.; Song, I.K. Methane production from carbon monoxide and hydrogen over nickel-alumina xerogel catalyst: Effect of nickel content. J. Ind. Eng. Chem. 2011, 17, 154-157. [CrossRef]

12. Fan, M.T.; Miao, K.P.; Lin, J.D.; Zhang, H.B.; Liao, D.W. Mg-Al oxide supported Ni catalysts with enhanced stability for efficient synthetic natural gas from syngas. Appl. Surf. Sci. 2014, 307, 682-688. [CrossRef]

13. Bradford, M.C.; Vannice, M.A. Catalytic reforming of methane with carbon-dioxide over nickel-catalysts I. Catalyst characterization and activity. Appl. Catal. A Gen. 1996, 142, 73-96. [CrossRef]

14. Nakayama, T.; Ichikuni, N.; Sato, S.; Nozaki, F. Ni/MgO catalyst prepared using citric acid for hydrogenation of carbon dioxide. Appl. Catal. A Gen. 1997, 158, 185-199. [CrossRef]

15. Xu, Y.; Cheng, C.; Du, S.; Yang, J.; Yu, B.; Luo, J.; Yin, W.; Li, E.; Dong, S.; Ye, P. Contacts between twoand three-dimensional materials: Ohmic, schottky, and p-n heterojunctions. ACS Nano 2016, 10, 4895-4919. [CrossRef] [PubMed]

16. Feng, J.; He, Y.; Liu, Y.; Du, Y.; Li, D. Cheminform abstract: Supported catalysts based on layered double hydroxides for catalytic oxidation and hydrogenation: General functionality and promising application prospects. Cheminform 2015, 46, 5291-5319. [CrossRef]

17. Bian, L.; Wang, W.; Xia, R.; Li, Z. Ni-based catalyst derived from Ni/Al hydrotalcite-like compounds by the urea hydrolysis method for CO methanation. RSC Adv. 2015, 6, 677-686. [CrossRef]

18. Hwang, S.; Hong, U.G.; Lee, J.; Seo, J.G.; Baik, J.H.; Dong, J.K.; Lim, H.; Song, I.K. Methanation of carbon dioxide over mesoporous $\mathrm{Ni}-\mathrm{Fe}-\mathrm{Al}_{2} \mathrm{O}_{3}$ catalysts prepared by a coprecipitation method: Effect of precipitation agent. J. Ind. Eng. Chem. 2013, 19, 2016-2021. [CrossRef]

19. Mitsudome, T.; Noujima, A.; Mizugaki, T.; Jitsukawa, K.; Kaneda, K. Cheminform abstract: Supported gold nanoparticles as a reusable catalyst for synthesis of lactones from diols using molecular oxygen as an oxidant under mild conditions. Green Chem. 2009, 11, 793-797. [CrossRef]

20. Liu, P.; Li, P.C.; Hensen, P.E.J.M. Efficient tandem synthesis of methyl esters and imines by using versatile hydrotalcite-supported gold nanoparticles. Chemistry 2012, 18, 12122-12129. [CrossRef] [PubMed]

21. Li, Z.; Bian, L.; Zhu, Q.; Wang, W. Ni-based catalyst derived from Ni/Mg/Al hydrotalcite-like compounds and its activity in the methanation of carbon monoxide. Kinet. Catal. 2014, 55, 217-223. [CrossRef]

22. Buelens, L.C.; Galvita, V.; Poelman, H.; Detavernier, C.; Marin, G.B. Super-dry reforming of methane intensifies $\mathrm{CO}_{2}$ utilization via le chatelier's principle. Science 2016, 354, 449-452. [CrossRef] [PubMed]

23. Dan, J.; Huang, X.; Li, P.; Zhang, Y.; Zhu, M.; Guo, X.; Dai, B.; Wang, Q.; Yu, F. Two-dimensional porous silica nanomesh from expanded multilayered vermiculite via mixed acid leaching. Nanosci. Nanotechnol. Lett. 2016, 8, 1028-1032. [CrossRef]

24. Li, P.; Wen, B.; Yu, F.; Zhu, M.; Guo, X.; Han, Y.; Kang, L.; Huang, X.; Dan, J.; Ouyang, F. High efficient nickel/vermiculite catalyst prepared via microwave irradiation-assisted synthesis for carbon monoxide methanation. Fuel 2016, 171, 263-269. [CrossRef]

25. Feng, Y.; Yang, W.; Chu, W. Effect of ca modification on the catalytic performance of Ni/AC for comethanation. Integr. Ferroelectr. 2016, 172, 40-48. [CrossRef]

26. Hwang, S.; Lee, J.; Hong, U.G.; Ji, C.J.; Dong, J.K.; Lim, H.; Byun, C.; Song, I.K. Hydrogenation of carbon monoxide to methane over mesoporous nickel-m-alumina ( $\mathrm{Fe}, \mathrm{Ni}, \mathrm{CO}, \mathrm{Ce}$, and $\mathrm{La})$ xerogel catalysts. J. Ind. Eng. Chem. 2012, 18, 243-248. [CrossRef] 
27. Hwang, S.; Hong, U.G.; Lee, J.; Baik, J.H.; Dong, J.K.; Lim, H.; Song, I.K. Methanation of carbon dioxide over mesoporous Nickel-M-Alumina ( $M=\mathrm{Fe}, \mathrm{Zr}, \mathrm{Ni}, \mathrm{Y}$, and $\mathrm{Mg}$ ) xerogel catalysts: Effect of second metal. Catal. Lett. 2012, 142, 860-868. [CrossRef]

28. Fornasari, G.; Gazzano, M.; Matteuzzi, D.; Trifirò, F.; Vaccari, A. Structure and reactivity of high-surface-area $\mathrm{Ni} / \mathrm{Mg} / \mathrm{Al}$ mixed oxides. Appl. Clay Sci. 1995, 10, 69-82. [CrossRef]

29. Olsbye, U.; Akporiaye, D.; Rytter, E.; Rønnekleiv, M.; Tangstad, E. On the stability of mixed $\mathrm{M}^{2+} / \mathrm{M}^{3+}$ oxides. Appl. Catal. A Gen. 2002, 224, 39-49. [CrossRef]

30. He, L.; Lin, Q.; Liu, Y.; Huang, Y. Unique catalysis of ni-al hydrotalcite derived catalyst in $\mathrm{CO}_{2}$ methanation: Cooperative effect between ni nanoparticles and a basic support. J. Energy Chem. 2014, 23, 587-592. [CrossRef]

31. Kustov, A.L.; Frey, A.M.; Larsen, K.E.; Johannessen, T.; Nørskov, J.K.; Christensen, C.H. CO methanation over supported bimetallic Ni-Fe catalysts: From computational studies towards catalyst optimization. Appl. Catal. A Gen. 2007, 320, 98-104. [CrossRef]

(C) 2017 by the authors. Licensee MDPI, Basel, Switzerland. This article is an open access article distributed under the terms and conditions of the Creative Commons Attribution (CC BY) license (http:/ / creativecommons.org/licenses/by/4.0/). 